\title{
PERILAKU DAN PERSEPSI MASYARAKAT TERHADAP PROGRAM PENGELOLAAN LIMBAH CAIR DOMESTIK DENGAN SISTEM SANITASI TERPUSAT DI KECAMATAN GUBENG SURABAYA
}

\author{
Sukriyah Kustanti
}

\begin{abstract}
Abstraksi
Pertambahan jumlah penduduk berpengaruh pada peningkatan jumlah limbah domestik yang dihasilkan, sehingga membawa dampak terjadinya pencemaran lingkungan alam. Salah satu wadah penampung limbah domestik adalah saluran-saluran drainase. Seringkali pula berfungsi sebagai tempat buangan limbah dari kegiatan dapur dan kamar mandi beserta tinjanya. Saluran Kalidami adalah salah satu saluran hulu yang berasal dari 3 buah anak saluran yakni saluran Pucang Anom Timur, Saluran Pucang Adi, dan Saluran Kertajaya, yang semuanya itu bermuara di Saluran Kalidami. Kualitas Saluran Kalidami terkait dengan ditetapkannya Peraturan Daerah Kota Surabaya Nomor : 02 tahun 2004, tentang Pengolahan Kualitas air dan Pengendalian Pencemaran Air sebagai badan air dengan klasifikasi kelas III. Salah satu poko permasalahan dalam melihat pengelolaan saluran-saluran tersebut adalah peran serta masyarakat, yang dalam hal ini merupakan kajian dalam penelitian ini.

Peran serta masyarakat terkait dengan bagaimana sikap dan perilaku masyarakat tersebut terhadap obyeknya. Studi kasus dalam penelitian ini adalah untuk melihat sejauh mana peran serta masyarakat di sepanjang anak Saluran Kalidami terhadap pengelolaan limbah cair domestik di sepanjang saluran drainase tersebut. Tujuan penelitian untuk melihat peran serta masyarakat di sepanjang saluran tersebut. Penelitian bersifat deskriptif, dengan teknik penarikan sampling random /acak terhadap sampel penelitian. Metode pengumpulan data adalah observasi dan survei lapangan, serta wawancara terbuka maupun wawancara dengan kuesioner. Hasil Penelitian menunjukkan tinkat pemahaman responden positif, demikian pula untuk sikap masyarakatnya. Namun tidak berhubungan dan berkontribusi terhadap perilaku dan peranserta masyarakat. Sehingga disimpulkan bahwa aspek ekonomi tidak berkaitan dengan faktor peranserta masyarakat, namun lebih pada aspek nilai budaya masyarakat.
\end{abstract}

Kata kunci : persepsi, sikap dan perilaku 
Pembangunan adalah upaya untuk meningkatkan kesejahteraan manusia khususnya dan Negara umumnya. Awalnya adalah pembangunan secara fisik saja yang mengacu pada kebijakan ekonomi dan kurang memperhatikan aspek lingkungan. Ketika menimbulkan dampak yang lebih serius dan meluas maka, mendorong manusia untuk menciptakan teknologi yang bersifat ramah lingkungan, yang kemudian dikembangkan secara luas dan dijadikan sebagai bagian dari pembangunan. Kerusakan lingkungan yang ditandai adanya perubahan ekosistem secara global, membuka mata masyarakat akan pentingnya pembangunan yang tidak hanya maju secara ekonomi namun juga berwawasan lingkungan yang berkelanjutan.

Surabaya adalah kota kedua terbesar di Indonesia, dengan jumlah penduduk yang setiap tahunnya dapat dikatakan bertambah. Bertambahnya jumlah penduduk juga membawa dampak pada pertambahan jumlah limbah domestik yang dihasilkan yang dapat membawa pencemaran lingkungan alam, baik di daratan maupun di perairan, demikian pula terhadap kondisi kualitas air. Kualitas air yang buruk dapat diamati dengan mudah pada saluran-saluran yang ada di sepanjang kota. Lebih dari itu saluran juga seringkali berfungsi sebagai tempat buangan limbah dari kegiatan dapur dan kamar mandi beserta tinjanya. Saluran Kalidami adalah salah satu saluran hulu yang berasal dari 3 buah anak saluran yakni saluran Pucang Anom Timur, Saluran Pucang Adi, dan Saluran Kertajaya, yang semuanya itu bermuara di Saluran Kalidami. Kualitas Saluran Kalidami terkait dengan ditetapkannya Peraturan Daerah Kota Surabaya Nomor : 02 tahun 2004, tentang Pengolahan Kualitas air dan Pengendalian Pencemaran Air sebagai badan air dengan klasifikasi kelas III, yaitu air yang peruntukannya dapat digunakan untuk pembudidayaan ikan air tawar dan air payau, peternakan, air untuk mengairi pertamanan, dan/atau peruntukan lain yang mensyaratkan mutu air yang sama dengan kegunaan tersebut. Peran serta masyarakat dalam hal ini mempunyai kajian penting dalam pengelolaan air dalam saluran-saluran pada umumnya. Karena peran serta masyarakat terkait 
pula bagaimana persepsi, sikap dan perilaku masyarakat tersebut terhadap obyeknya.

Penelitian ini merumuskan permasalahannya adalah sebagai berikut : Sejauh mana Persepsi, sikap dan perilaku masyarakat dan peran serta masyarakat dan pemerintah dalam pengelolaan air limbah cair domestik di saluran drainase Kalidami tersebut? Adapun Tujuan dari penelitian ini adalah untuk melihat persepsi, sikap, perilaku dan peran serta masyarakat di sepanjang saluran Kalidami tersebut terhadap pengelolaan limbah cair domestik. Sedangkan Manfaat dari penelitian : Memberikan kontribusi pada Pusat-Pusat Penelitian khususnya sebagai data base tentang kondisi sosial masyarakat yang tinggal sepanjang drainase saluran buangan khususnya di lokasi penelitian dan umumnya di sepanjang saluran draimnase. Sehingga dapat memberi masukan pada pihak terkait baik Lingkungan Hidup Pemda setempat misalnya, tentang Pola Pengelolaan Limbah Cair Domestik sepanjang saluran drainase dengan system sanitasi terpusat.

Metodologi Penelitian adalah penelitian yang bersifat lapangan (survei), sehingga data yang dibutuhkan menyangkut data Primer dan data Sekunder. Data Primer adalah yang didapatkan di tempat wilayah penelitian, sedangkan data Sekunder adalah dari Lembaga terkait untuk peraturan-Peraturan yang ada untuk Saluran Drainase Kalidami Adapun Metode Penelitian adalah sebagai berikut :

1. Survei dan observasi lapangan

2. Pengumpulan data primer dan sekunder

3. Wawancara dengan kuesioner terhadap responden terpilih sebagai sample penelitian

4. Wawancara dengan instansi/kelembagaan yang berwenang terhadap Saluran

Drainase Kalidami. 
Teknik Pengumpulan data sebagai berikut, yakni dengan a). teknik penarikan sampel

secara acak random sampling. Populasi dan Sampel penelitian adalah seluruh masyarakat

Berdasarkan data Kecamatan Gubeng Dalam Angka tahun 2004, jumlah Penduduk

sebanyak 66.957 jiwa. Berdasarkan teori Singarimbun (1989), jumlah penarikan sampling

dengan rumus :

$$
\begin{aligned}
& \text { n }
\end{aligned}
$$

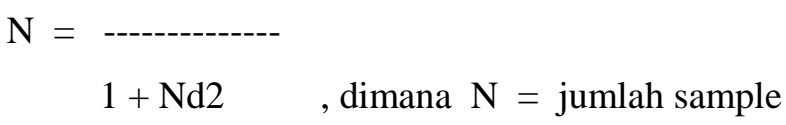

$$
\begin{aligned}
& \mathrm{n}=\text { jumlah populasi } \\
& \mathrm{d}=\text { derajad kecermatan }(10 \%)
\end{aligned}
$$

Sehingga jumlah sample dalam penelitian ini adalah 100 jiwa, yang dalam hal ini sampel

penelitian adalah Keluarga (bisa bapak atau ibu) dan yang tersebar di tiga kelurahan yakni :

Kelurahan Pucang Anom Timur, Kelurahan Pucang Adi dan Kelurahan Kertajaya,

Kecamatan Gubeng, kotamadya Surabaya. Variabel Penelitian adalah : Pengetahuan, Sikap,

dan Tindakan/perilaku/motivas yang tersusun dalam daftar pertanyaan/kuesioner untuk

masyarakat. b). Teknik Pengolahan data Pengolahan data dengan Proporsi Persentase terhadap hasil

kuesioner dalam Tabulasi Freqwensi., c). Analisa data dengan analisa deskriptif hasil tabulasi. 


\section{Teori Lingkungan Hidup}

Ekosistem mempunyai kemampuan untuk menahan berbagai perubahan dalam sistem secara keseluruhan. Kadangkala kemampuan ini dapat diterobos oleh kegiatan manusia, seperti misalnya : sungai dikotori oleh pembuangan sampah. Bila sampah itu tidak terlalu banyak, maka akan secara alami sungai itu dapat dijernihkan kembali airnya, tetapi bila sampah yang masuk terlalu banyak, maka batas-batas kemampuannya tidak lagi mempunyai mekanisme alami yang pada akhirnya secara permanen air itu rusak.Untuk itu diperlukan analisis peran lingkungan terhadap aktivitas manusia, yang dalam hal ini dapat ditinjauan dari berbagai aspek, antara lain aspek politis, tinjauan aspek ekonomis, dan tinjauan aspek sosial.

\section{Teori Persepsi, Sikap, Perilaku dan Peran serta Masyarakat}

Perilaku manusia terhadap lingkungan terkait dengan bagaimana manusia tersebut memberi arti terhadap lingkungan hidup. Oleh karena itu menurut Soemarwoto (1989), ada tiga macam perilaku manusia terhadap lingkungan, yakni perilaku merusak, perilaku kesadaran dan perilaku melestarikan lingkungan. Seringkali ada aspek-aspek ketidaktahuan/ketidak mengertian manusia bertindak terhadap lingkungan, bisa karena kurangnya informasi atau kurangnya komunikasi, yang pada mereka merupakan penyebab kerusakan lingkungan. Umumnya hal ini terjadi pada penduduk pedesaan yang jauh dari informasi dan komunikasi dan masyarakat miskin yang tinggal di pinggiran kota atau masyarakat yang berada di sepanjang sungai. Informasi dalam lingkungan hidup dikatakan sebagai suatu hal yang memberikan pengetahuan, dan ini dapat berwujud benda fisik atau bahkan pula dapat berbentuk kelakuan (Soemarwoto, 1988).

Manusia bagian dari ekosistem tersebut diatas, dalam kehidupannya mempunyai kaitan dengan makhluk hidup lain yakni tumbuhan dan hewan. Ketergantungan ini mempunyai implikasi bahwa, semua komponen mempunyai peran yang sama penting, sehingga eksistensi semua makhluk hidup serta kesejahteraannya juga harus di pelihara. 
Asa tiga hal yang dapat dilakukan manusia dalam memelihara keseimbangan antara koreksi sikap (yakni : sikap manusia terhadap lingkungan hidup), dan koreksi teknologi yang digunakan serta koreksi alami ( ekosistem ). Hubungan antara ketiga tersebut, tergambar dalam skema di bawah ini :

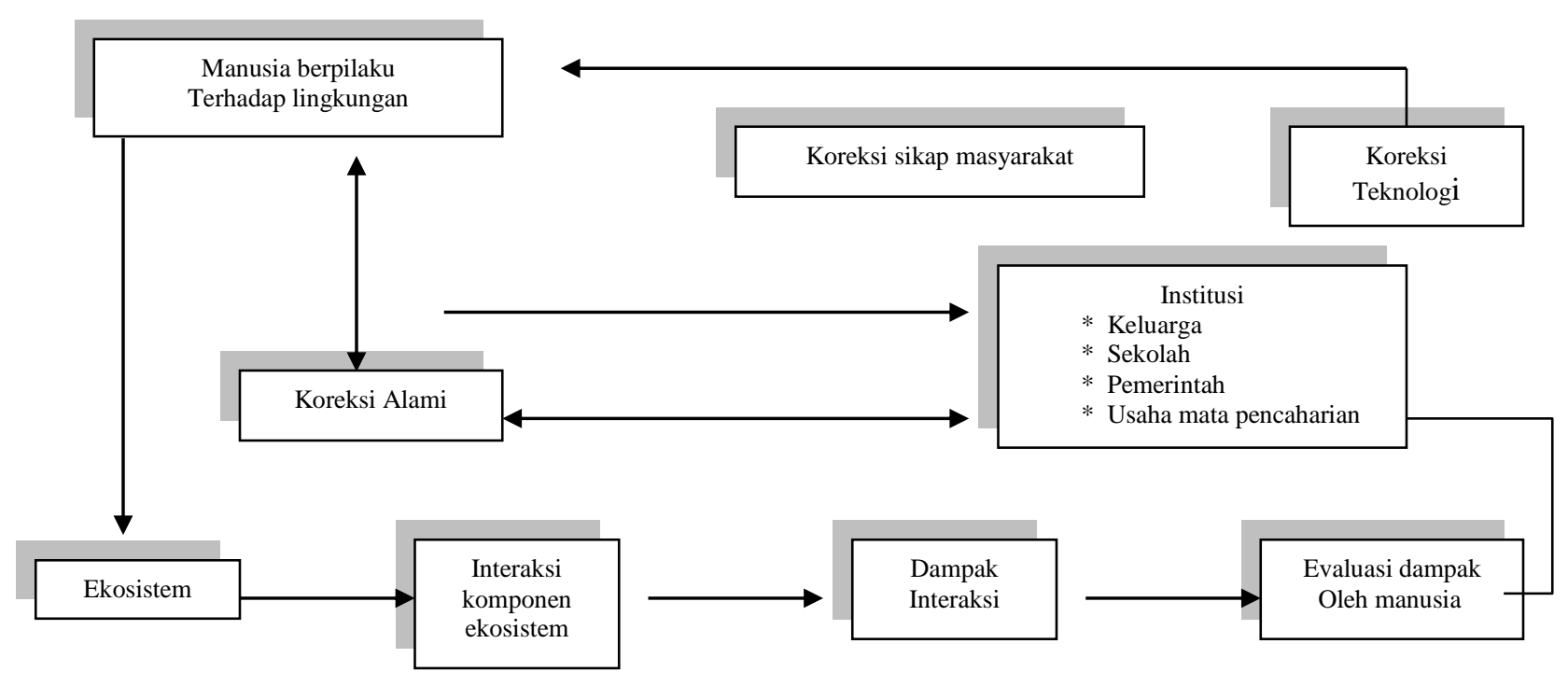

Interaksi antara manusia dengan komponen lain dalam ekosistem, dimana manusia perlu diimbangi dengan mengatur keserasian, antara sikap masyarkat, penggunaan teknologi dan koreksi alami dan disertai Kelembagaan (Soerjani, 1990).

Koreksi sikap manusia terhadap lingkungan, nampak dalam kehidupan manusia bermasyarakat, yakni terjadi proses pengaruh mempengaruhi akal pikiran melalui dialog, baik dialog langsung maupun tak langsung. Dalam hubungan ini terjadi proses pengaruh mempengaruhi antara akal, pikiran, dan sikap perbuatanmanusia. Adanya aktivitas manusia umumnya berusaha menyesuaikan diri, memlihara, serta mengelola lingkungan. Akibat dari aktivitas manusia dapat mengakibatkan beberapa perubahan, baik perubahan yang bersifat perkembangan ataupun perubahan lokasi/tempat, serta perubahan tata laku/perilaku, yang satu sama lain saling berhubungan. Lebih lanjut oleh Bintarto (1983), dikatakan bahwa perubahan tata laku/perilaku merupakan perubahan sikap individu dalam menyesuaikan diri dengan perkembangan lingkungan 
yang terjadi. Koentjaraningrat (1974), mengatakan bahwa pengetahuan dan pemahaman yang didapatkan dapat dijadikan acuan sikap individu terhadap suatu obyek, sehingga pengetahuan akan suatu program/kegiatan bagi diri individu biasanya akan menghasilkan partisipasi yang spontan sifatnya. Dengan mempunyai sikap yang baik maka dapat diharapkan dapat berpartisipasi dengan baik pula.

\section{Karakteristik Limbah Cair Domestik.}

Pengelolaan limbah cair domestik sangat terkait dengan peran serta masyarakatnya dan fasilitas yang tersedia di tempat tersebut. Pengertian air limbah menurut Lee (2000), adalah buangan yang dihimpun dari limbah perumahan, manusia, hewan, industri, limpasan hujan dan rembesan air tanah yang terdiri dari 99,94\% berat air dan 0,06\% material terlarut. Sedangkan batasan air limbah menurut Metcalf dan Eddy (1981) adalah kombinasi cairan dan sampah cair yang berasal dari daerah pemukiman, perdagangan, perkantoran dan industri bersama-sama air tanah, air permukaan dan air hujan. Tjokrokusumo (1998) dalam Pitoy (2004) menyatakan bahwa air limbah merupakan air buangan yang diartikan sebagai kejadian masuknya atau dimasukkannya benda padat, cair, dan gas kedalam air dengan sifatnya yang berupa endapan atau padatan, padat tersuspensi, terlarut sebagai koloid teremulasi yang menyebabkan air dimaksud harus dipisahkan atau di buang. Air limbah domestik terbagi menjadi dua macam yakni, limbah dari dapur, kamar mandi dan mencuci yang disebut greywater, dan limbah yang berkaitan dengan buangan dari tangki septik, kotoran manusia, lumpur dan urine yang disebut blackwater. Sedangkan karakteristik air limbah domestik ini bisa dilihat dari sifat fisik, sifat kimia dan sifat biologi.

Menurut Metcalf dan Eddy (1991) Combined System adalah sistem penyaluran yang menyalurkan air limbah domestik dan juga run-off atau limpasan hujan secara bersama-sama, sedangkan menurut Lee (2000), Combined Sewers adalah bangunan pengumpul dan penyalur limbah cair domestik, limbah industri, dan limpasan air hujan yang menjadi satu saluran. 
Adapun prinsip pengaliran menurut Mara (1975) sistem pengaliran air limbah haruslah mencakup sistem pengaliran 1). Jalur saluran harus dibuat sepanjang mungkin dengan maksimal waktu perjalanan $18 \mathrm{jam}, 2$ ). Aliran air harus lancar sedapat mungkin membawa benda-benda padatan didalamnya secara terus menerus, tidak terhenti atau mengendap untuk mencegah timbulnya pembusukan yang dapat menimbulkan bau, gas yang tidak enak dan berbahaya, 3). Kemiringan saluran diusahakan mengikuti kemiringan muka tanah dan diusahakan untuk mempunyai kecepatan pengaliran yang self cleansing velocity dan tidak merusak saluran.

Lebih lanjut menurut Mara (1975) sistem ideal Penyelenggaraan pengelolaan air buangan harus memenuhi seluruh kreteria-kreteria dibawah ini :1). Kesehatan, 2) penggunaan ulang, 3) Ekologis, 4) gangguan, 5) Kebudayaan, 6) operasional, 7) biaya. Sedangkan data pendukung yang dibutuhkan untuk sistem penyaluran air buangan limbah ini antara lain: kepadatan penduduk, sistem penyediaan air bersih, keadaan tanah, topografi, kemampuan membangun dan membiayai perawatan/pemeliharaan serta fasilitas pembuangan air limbah yang ada.

Menurut Barid (2005) Sanitasi air buangan adalah pengelolaan air buangan sebelum masuk kedalam air alam. Adapun langkah pertama yang harus ditempuh dalam peningkatan penggunaan sarana sanitasi adalah pemberian pengetahuan (penyuluhan) kepada khalayak masyarakat mengenai pentingnya perilaku hidup bersih dan sehat, dimana salah satunya adalah penggunaan jamban dalam kehidupan seharihari. Bila masyarakat telah menyadari pentingnya sanitasi, khususnya yang berkaitan dengan kesehatan dan produktifitas, maka kebutuhan terhadap sarana dan prasarana sanitasi meningkat. Sehingga dalam rangka pemenuhan kebutuhan sanitasi ini, pemerintah, wakil rakyat dan swasta perlu diberi penjelasan mengenai pentingnya persoalan sanitasi, sehingga mereka memberikan dukungan terhadap pelaksanaan program sanitasi. Oleh karenanya peran serta masyarakat dalam pelibatannya terhadap program-program pemerintah memerlukan suatu kajian yang mendalam. Untuk itulah penelitian ini dilakukan di wilayah sepanjang saluran Kalidami khususnya, yang berada di Kecamatan Gubeng Kotamadya Surabaya.

\section{HASIL DAN PEMBAHASAN}




\section{Gambaran Umum Responden}

Penelitian ini berhasil mewawancarai sejumlah 100 orang responden yang berada di wilayah studi. Gambaran umum responden diuraikan dalam tabel dibawah ini yang meliputi : jenis kelamin, umur, pendidikan, pekerjaan dan pendapatan.

Tabel : Identitas Responden di wilayah studi sejumlah (100) orang.

\begin{tabular}{|c|c|c|c|}
\hline I & JENIS KELAMIN & JUMLAH & PROSENTASE \\
\hline 1 & Pria & 63 & 63 \\
\hline \multirow[t]{2}{*}{2} & Perempuan & 37 & 37 \\
\hline & TOTAL & 100 & 100 \\
\hline II & UMUR & JUMLAH & PROSENTASE \\
\hline 1 & 17 - 27 Tahun & 11 & 11 \\
\hline 2 & $28-38$ tahun & 28 & 28 \\
\hline 3 & $39-49$ tahun & 57 & 57 \\
\hline \multirow[t]{2}{*}{4} & $>50$ tahun & 34 & 34 \\
\hline & TOTAL & 100 & 100 \\
\hline III & PENDIDIKAN & JUMLAH & PROSENTASE \\
\hline 1 & SD & 5 & 5 \\
\hline 2 & SLTP & 17 & 17 \\
\hline 3 & SLTA & 58 & 58 \\
\hline \multirow[t]{2}{*}{4} & Sarjana (PT) dan Akademi & 20 & 20 \\
\hline & TOTAL & 100 & 100 \\
\hline IV & PEKERJAAN & JUMLAH & PROSENTASE \\
\hline 1 & Pegawai Negeri & 13 & 13 \\
\hline 2 & Pedagang & 22 & 22 \\
\hline 3 & Wiraswasta & 23 & 23 \\
\hline 4 & Buruh & 11 & 11 \\
\hline 5 & Karyawan & 15 & 15 \\
\hline \multirow[t]{2}{*}{6} & Lain-lain/Jasa & 16 & 16 \\
\hline & TOTAL & 100 & 100 \\
\hline $\mathrm{V}$ & PENDAPATAN & JUMLAH & PROSENTASE \\
\hline 1 & < Rp. 600.000,- & 14 & 14 \\
\hline
\end{tabular}




\begin{tabular}{|c|c|c|c|}
\hline 2 & Rp. $650.000 \quad--\quad$ Rp. 1.000 .000 & 25 & 25 \\
\hline 3 & Rp. 1.000 .000 -- Rp. 1.500 .000 & 42 & 42 \\
\hline 4 & $>$ Rp. 1.500 .000 & 19 & 19 \\
\hline & TOTAL & 100 & 100 \\
\hline
\end{tabular}

Gambaran identitas responden tersebut diatas terlihat bahwa responden terbanyak ada di usia 39 - 49 tahun sebanyak (57\%), kedua adalah responden yang berada di atas usia 50 tahun sebanyak (34\%). Sedangkan tingkat pendidikan responden tertinggi adalah Akademi dan Sarjana ada sejumlah (28\%), namun jumlah terbanyak adalah responden yang berpendidikan SLTA ada $(50 \%)$. Jenis pekerjaan responden hampir merata namun tetap terbanyak ada di sektor wiraswasta (23\%), dan pedagang sebesar (22\%), serta jenis pekerjaan lain-lain/jasa juga cukup banyak ada (16\%). Demikian pula tingkat pendapatan responden sudah terkecil berada di tingkat UMR sebanyak (14 \%), dan tertinggi diatas Rp.1.500.000,- sejumlah (19\%), sedangkan terbanyak responden yang berpendapatan antara Rp.1.000.000,--- Rp. 1.500.000,- ada (42\%). Responden adalah kepala keluarga yang berada di tempat wilayah studi. Adapun Infrastruktur yang dimiliki dan dilakukan oleh responden adalah sebagai berikut dalam tabel dibawah.

\section{Infrastruktur, Sarana dan Prasarana Responden}

Adapun Infrastruktur yang dimiliki oleh responden adalah sebagai berikut.

Tabel : Infrastruktur responden

\begin{tabular}{|c|l|c|c|}
\hline I & PENGGUNAAN SISTEM MCK & JUMLAH & PROSENTASE \\
\hline 1 & Septik tank & 15 & 15 \\
\hline 2 & Selokan & 18 & 18 \\
\hline 3 & Masuk ke sungai & 67 & 67 \\
\hline & & 100 & 100 \\
& TOTAL & & \\
\hline II & SISTEM PEMBUANGAN TINJA & JUMLAH & PROSENTASE \\
\hline
\end{tabular}




\begin{tabular}{|c|c|c|c|}
\hline 1 & Septik tank & 15 & 15 \\
\hline 2 & Selokan & 23 & 23 \\
\hline \multirow[t]{2}{*}{3} & Masuk ke sungai & 62 & 62 \\
\hline & TOTAL & 100 & 100 \\
\hline III & SISTEM PEMBUANGAN SAMPAH & JUMLAH & PROSENTASE \\
\hline 1 & Komunal & 23 & 23 \\
\hline 2 & Dibakar & 39 & 39 \\
\hline \multirow[t]{2}{*}{3} & Dibuang ke sungai & 38 & 38 \\
\hline & TOTAL & 100 & 100 \\
\hline IV & PENGANGKUTAN SAMPAH & JUMLAH & PROSENTASE \\
\hline 1 & Setiap hari & 11 & 47,9 \\
\hline 2 & Dua hari sekali & 8 & 34,7 \\
\hline \multirow[t]{2}{*}{3} & Jika dibutuhkan / kadang 3 hari sekali & 4 & 17,4 \\
\hline & TOTAL & 23 & 100 \\
\hline $\mathrm{V}$ & IURAN SAMPAH SETIAP BULAN & JUMLAH & PROSENTASE \\
\hline 1 & Rp. $2.500,-$ & 2 & \\
\hline 2 & Rp. 5.000,- & 10 & \\
\hline \multirow[t]{2}{*}{3} & Rp. 10.000,- & 11 & \\
\hline & TOTAL & 23 & 100 \\
\hline
\end{tabular}

Ada sejumlah $(67 \%)$ responden yang sistem MCK nya adalah masuk ke sungai, dan ada (18\%) responden sistem MCK nya adalah ke selokan dan hanya (15 $\%)$ responden yang menggunakan septik tank ditempat tinggalnya. Sedangkan Sistem pembuanga tinja bagi sejumlah (62\%) adalah masuk ke sungai, dan $(23 \%)$ responden adalah masuk ke selokan, dan $(15 \%)$ responden menggunakan septik tank. Selanjutnya untuk sistem pembuangan sampah sejumlah responden (39\%) adalah dengan cara membakar, dan (38\%) dengan cara di buang ke sungai, sisanya (23\%) dengan cara 
komunal yakni dengan sistem TPS. Adapun yang menggunakan TPS tersebut sejumlah $(47,9 \%)$ atau 11 orang responden mengatakan pengangkutan sampah pada setiap hari, dan $(34,7 \%)$ atau 8 orang responden mengatakan dua hari sekali sampah-sampah diangkut, serta $(17,4 \%)$ responden mengatakan kadang-kadang hingga tiga hari baru diangkut bahkan jika dibutuhkan maka pengangkutnya datang. Adapun iuran yang dikeluarkan responden yang cara pengelolaan sampah komunal tersebut tertinggi adalah Rp. 10.000,-. Lebih lanjut jika dilihat dari tingkat pemahaman (kognitif) responden terhadap drainase yang diukur dengan skala yakni jawaban ya, tidak, dan tidak menjawab, seperti yang terrinci dalam tabel dibawah ini.

\section{Persepsi Responden Terhadap Sistem Drainase}

Persepsi atau tingkat pemahaman responden nampak dalam uraian tabel di bawah ini.

Tabel : Tingkat Pemahaman Responden terhadap sistem drainase (100 ) orang

\begin{tabular}{|c|c|c|c|c|}
\hline No & Uraian & $\mathrm{Ya}$ & Tidak & Tidak menjawab \\
\hline 1 & Mengerti fungsi sistem drainase & $67(67 \%)$ & $19(19 \%)$ & $10(10 \%)$ \\
\hline 2 & Apakah saluran selalu mengalir baik & $60(60 \%)$ & $32(32 \%)$ & $8 \quad(8 \%)$ \\
\hline 3 & Apakah air saluran berbau & $69(69 \%)$ & $20(20 \%)$ & $11 \quad(11 \%)$ \\
\hline 4 & $\begin{array}{l}\text { Apakah anda sering melihat } \\
\text { penumpukan sampah di saluran tsb. }\end{array}$ & $54(54 \%)$ & $34(34 \%)$ & $12(12 \%)$ \\
\hline 5 & Limbah cair domestik & $51(58 \%)$ & $37(37 \%)$ & $12(12 \%)$ \\
\hline 6 & Dampak limbah cair domestik & $55(55 \%)$ & $32(42 \%)$ & $13(13 \%)$ \\
\hline 7 & $\begin{array}{l}\text { Apakah ada petugas pembersih untuk } \\
\text { saluran tersebut }\end{array}$ & $15(15 \%)$ & $72(72 \%)$ & $13(13 \%)$ \\
\hline
\end{tabular}

Tingkat pemahaman responden jika dilihat dari hasil tabel diatas, sejumlah (67\%) responden menyatakan "ya", artinya mereka memahami arti fungsi sistem drainase, walaupun masih terdapat 19 orang (19\%) yang menyatakan tidak mengerti dan (10\%) responden yang tidak menjawab. Lebih lanjut jika dilihat perolehan nomor 2 yakni apakah saluran selalu mengalir baik, ada sejumlah (60\%) responden yang menyatakan 
"ya", demikian pula tentang air saluran yang berbau ada sejumlah (54 \%) menyatakan "ya", serta tentang limbah domestik ada sejumlah (50\%) responden menyatakan "ya". Dengan demikian perolehan tentang pemahaman responden tergolong baik artinya responden memahami arti, fungsi drainase bagi lingkungan alam khususnya, dan lingkungan masyarakat umumnya. Walaupun masih juga ada responden yang tidak menjawab. Adapun alasan mereka yang tidak menjawab tersebut adalah karena tidak tahu dan kelihatan ragu dalam menjawabnya. Lebih lanjut bila dilihat dari sikap responden terhadap sistem drainase sebagai berikut dalam tabel dibawah ini.

\section{Sikap Responden Terhadap Sistem Drainase}

Dalam teori Psikologi Sikap seseorang adalah pencerminan dalam hatinya, oleh karena sikap

diistilahkan sebagai kecenderungan untuk berperilaku terhadap suatu obyek yang ditunjukkan

dengan jawaban setuju atau tidak setuju atau tidak menjawab seperti dalam

uraian tabel di

bawah ini.

Tabel : Sikap responden terhadap sistem drainase

\begin{tabular}{|c|l|c|c|c|}
\hline No & \multicolumn{1}{|c|}{ Uraian } & Setuju & Tidak setuju & $\begin{array}{c}\text { Tidak } \\
\text { menjawab }\end{array}$ \\
\hline 1 & $\begin{array}{l}\text { Menurut anda apakah limbah cair domestik perlu } \\
\text { diolah }\end{array}$ & $87(87 \%)$ & $5(5 \%)$ & $8 \%)$ \\
\hline 2 & $\begin{array}{l}\text { Bagaimana jika pengolahan limbah dilakukan secara } \\
\text { terpusat }\end{array}$ & $63(63 \%)$ & $25(25 \%)$ & $12(12 \%)$ \\
\hline 3 & $\begin{array}{l}\text { Apakah ada kerjabakti untuk membersihkan saluran } \\
\text { tersebut }\end{array}$ & $40(40 \%)$ & $52(52 \%)$ & $8(8 \%)$ \\
\hline 4 & \begin{tabular}{l} 
Apakah anda bersedia jika diharuskan setiap bulan \\
\hline
\end{tabular} & $38(38 \%)$ & $49(41 \%)$ & $13(13 \%)$ \\
\hline
\end{tabular}




\begin{tabular}{|c|l|c|c|c|}
\hline & kerja bakti warga & & & \\
\hline 5 & $\begin{array}{l}\text { Bagaimana jika pemerintah membuatkan pengolahan } \\
\text { limbah secara komunal di lingkungan sini }\end{array}$ & $84(84 \%)$ & $10(10 \%)$ & $6 \quad(6 \%)$ \\
\hline 6 & $\begin{array}{l}\text { Jika ada biaya perawatan, apakah anda bersedia } \\
\text { membayar setiap bulan }\end{array}$ & $29(29 \%)$ & $59(59 \%)$ & $12(12 \%)$ \\
\hline
\end{tabular}

Sikap responden menunjukkan sikap positif terhadap sistem drainase. Hal ini terlihat dari hasil kuesioner yang menyatakan "setuju" lebih besar jumlahnya dari pada yang "tidak setuju", walaupun tetap ada responden yang tidak menjawab dalam kuesioner tersebut. Alasan mereka menjawab tidak adalah karena responden menunjukkan perasaan raguragu/diam saja.

Selanjutnya jika hasil tersebut ditabulasi silang dengan variabel tingkat pendidikan adalah sebagai berikut

Tabel : Tabel silang antara Tingkat Pendidikan Responden dengan Mengerti fungsi sistem drainase

\begin{tabular}{|c|l|c|c|}
\hline No. & Pendidikan & Jumlah & Prosentasi \\
\hline 1 & SD & 2 & 2,98 \\
\hline 2 & SLTP & 9 & 13,43 \\
\hline 3 & SLTA & 41 & 61,19 \\
\hline 4 & Akademi dan Sarjana & 15 & 22,48 \\
\hline \multicolumn{2}{|r|}{ Total } & 67 & 100 \\
\hline
\end{tabular}

Nampaknya dari aspek pendidikan responden yang memahami tentang sistem drainase terbanyak adalah responden yang berpendidikan SLTA sebesar (61,19\%), dan responden yang berpendidikan Sarjana sebanyak (22,28 \%). Hasil wawancara dengan responden mereka seringkali mengikuti penyuluhan-penyuluhan dan juga seminar-seminar yang membahas tentang limbah dan saluran air serta drainase. Namun jika dilihat hasil perolehan bahwa Limbah domestik perlu diolah maka responden yang menjawab "ya" lebih banyak dari jumlah responden yang mengerti tentang drainase. Hal ini menunjukkan bahwa tingkat 
pemahaman responden tidak berkorelasi dengan sikap responden untuk menyetujui limbah domestik masuk ke sistem drainase perlu diolah.

Selanjutnya pernyataan bagaimana jika pengolahan limbah dilakukan secara terpusat, ada (63 $\%$ ) responden menyatakan setuju terhadap pernyataan tersebut. Namun sebaliknya jika dikorelasikan dengan pertanyaan apakah bersedia untuk diajak kerja bakti, hanya sejumlah (46 \%) responden yang menjawab "ya" artinya mereka bersedia. Jawaban kesediaan responden untuk ikut kerja bakti kami korelasikan dengan tingkat pendapatan responden seperti dalam tabel dibawah ini.

Tabel : Kesediaan responden untuk kerjabakti dengan korelasi pendapatan.

\begin{tabular}{|c|c|c|c|c|}
\hline \multirow{2}{*}{ No } & Pendapatan & \multicolumn{3}{|c|}{ Kesediaan kerjabakti } \\
\cline { 3 - 5 } & & Ya & Tidak & Total \\
\hline 1 & $<$ Rp. 600.000,- & $26(52,56 \%)$ & --- & $26(56,66 \%)$ \\
\hline 2 & Rp. 650.000 -- Rp. 1.000.000 & $14(30,43 \%)$ & $2(4,34 \%)$ & $16(36,81 \%)$ \\
\hline 3 & Rp. 1.000.000 -- Rp. 1.500.000 & $1(0,01)$ & $2(4,34 \%)$ & $3(6,52 \%)$ \\
\hline 4 & $>$ Rp. 1.500.000 & --- & $1(0,01 \%)$ & $1(0,01)$ \\
\hline \multicolumn{2}{|c|}{ Jumlah } & $41(89,14)$ & $5(10,86 \%)$ & $46(100)$ \\
\hline
\end{tabular}

Sejumlah responden yang menyatakan bersedia tersebut jika dikorelasikan dengan pendapatan responden ternyata justru yang terlihat adalah separo dari jumlah responden yang berpendapatan rendah yakni sebanyak 26 orang (56,52 \%). Sedangkan mereka yang tergolong ekonomi menengah ada sejumlah 17 orang (36,94\%) responden, hanya $2(4,34$ $\%)$ orang yang menyatakan tidak bersedia disebabkan "karena waktunya hanya untuk kerja cari uang setiap hari" dan juga menyatakan "sudah ada petugas yang bertugas sebagai pengelola dan pemantau saluran-saluran di seluruh kota Surabaya". Berbeda dengan responden lain yang menyatakan tidak bersedia tersebut mereka menyatakan "lebih baik saya membayar orang saja untuk ikut kerja bakti”. Pernyataan seperti ini menunjukkan sikap yang tidak bertoleransi dalam kehidupan bermasyarakat. Artinya kehidupan yang mengabaikan kebersamaan dan kegotongroyongan. Disisi lain bila ditinjau dari aspek kehidupan masyarakat di wilayah studi ini adalah masyarakat desa kota, yakni desa yang letaknya ada di 
tengah perkotaan. Dengan demikian corak kehidupan perkotaan yang individualis sudah masuk ke dalam kelompok masyarakat ini.

\section{Kesimpulan}

Hasil pembahasan tersebut diatas dapat disimpulkan bahwa dari Aspek pemahaman masyarakat tentang fungsi sistem drainase cukup baik dalam arti positif, walaupun masih masih terdapat responden yang tidak mau menjawab. Dilihat dari perolehan sikap masyarakat menunjukkan sikap positif, namun jika dilihat perolehan perilaku dan peranserta masyarakatnya adalah rendah.Jadi, jika dikorelasikan antara persepsi dan sikap masyarakat tidak berhubungan dengan perilaku dan peran serta masyarakat. Dengan demikian peranserta masyarakat tidak hanya bergantung pada aspek ekonomi saja namun juga pada aspek nilai budaya masyarakat.

\section{Daftar Pustaka}

Anonim. 2004. Himpunan Peraturan Tentang "Pengendalian pencemaran air di Kota Surabaya”. Dinas Lingkungan Hidup Kota Surabaya. Surabaya

Anonim. 1997. Drainase Perkotaan. Gunadarma. Jakarta.

Bintarto. 1983. Interaksi Desa-Desa dan Permasalahannya. Ghalia Indonesia. Jakarta.

Koentjaraningrat. 1974. Kebudayaan Metalitas dan Pembangunan. PT. Gramedia. Jakarta.

Metcall and Eddy. 1991. Waste Water Engineering: treatment. Disposal, and Reuse. Mc. Graw-Hill Inc. New York.

Moch. Soerjani. 1997. Kependudukan, Sumberdaya Alam dan Lingkungan Hidup. U.I. Pres. Jakarta.

Masri Singarimbun. 1989. Metodologi Penelitian. Pustaka. Jakarta

Otto Soemarwoto. 1988. Ekologi, Pembangunan dan Lingkungan Hidup. Djambatan. Jakarta.

Pitoyo, Joko. 2004. Evaluasi Sistem Pengumpulan dan Penyaluran Air Limbah Dengan Sistem Terpusat di Kota Banjarmasin. Jurusan Teknik Lingkungan Program Studi Teknik Prasarana Lingkungan Permukiman-ITS. Surabaya.

Sarlito Wirawan Sarwono. 1900. Psikologi Sosial. Lembaga Psikologi UI. Jakarta. 